MIHAELA MUDURE

\title{
THREE INSTANCES OF THE ROMANIAN ACADEMIC NOVEL
}

The "campus/ academic novel" entered literary taxonomy in the United States and United Kingdom of Great Britain, in the seventies and the eighties of the twentieth century. The appearance of this new literary form is not without connection with the new evolutions in the educational policies of the First World countries. The number of universities increased. The gates of the universities were open wider and wider giving young people false hopes that a university degree will give them respectability, wealth and a middle class status. This was certainly true for the Victorian Age and afterwards, up to World War II. Nowadays the universities are rather social tools in order to maintain a social status quo and postpone social crises as much as possible. What is the recipe? Firstly, high school is more and more lenient. Both high schools and universities are more and more assembly lines which offer the buyer (the student) a degree which is no longer the social opener it used to be. The entrance of the young generation into the labour market is delayed more and more by prolonging schooling, the youngsters' energies are contained as they must continue to yield to the authorities and the gate keepers extant. Therefore, students are being deprived of economic independence and held mesmerized by the mirage of the miraculous university degree that will bring them ever lasting fulfilment and the assurance that they will live happily ever after... Ever after graduation, of course.

In other words, the proliferation of the campus novel must be connected to the changes in the structure and the expected scope of the university in society. The university is no longer a place only for restricted and restrictive elites. More and more youngsters whose ancestors did not have more than elementary schooling are admitted to the university. Not only the studentship changed but also the teachers's condition. Many novelists teach in universities and are inspired by academic life. Remember the old adage: write what you know, write what you know about! Much more than before World War II writers became members of the academic staff. The appearance of the creative writing classes brought many writers into the academia.

In the past the literary circles and societies ${ }^{1}$ offered, for free, young or not so young writers the support, the guidance, the encouragement that creative writing classes are now offering within the universities, but not for free. Of course, writers have to live and the mercantile contemporary capitalism does not offer too many chances to someone interested in art. The solution? Turn writers (but not all of them, only the famous ones) into teachers of literary art.

\footnotetext{
${ }^{1}$ Junimea, Sburătorul, or Cenaclul de Luni are such literary circles in the Romanian literary history.
} 
On the other hand, truth is that writers used universities as fictional sites long before the appearance of the campus novel. In François The Life of Gargantua and Pantagruel (1534), the famous French university, la Sorbonne, was a favourite target for the laughter of the French Renaissance writer François Rabelais. Oxford appears in several eighteenth-century English novels. Education and learning were not a priority for many Oxonian students. Eliza Haywood wrote in The Adventures of Miss Betsy Thoughtless (1751) about the erotic preoccupations of the students in Oxford and the dangers modest ladies could encounter in this academic town:

The ladies of Oxford are commonly more than ordinarily circumspect in their behaviour; as indeed, it behoves them to be, in a place where there are such a number of young gentlemen, many of whom pursue pleasure more than study, and scruple nothing for the gratification of their desires. It is not, therefore, to be wondered at, that being from their infancy trained up in the most strict reserve, and accustomed to be upon their guard against even the most distant approaches of the other sex, they should be apt to pass the severest censures on a conduct, which they had been always taught to look upon as the sure destruction of reputation, and frequently fatal to innocence and virtue ${ }^{2}$.

In Tobias Smollett's epistolary novel The Expedition of Humphry Clinker (1771), there are two Oxonians: Jerry Melford and Sir Watkin Phillips. Their letters talk mostly about amorous escapades and consequences that must be hidden or dealt with in other discreet ways and not so much about exams or severe professors. Here is for instance, a fragment from one of Jerry Melford's letters. The epistle talks about the Oxonians' interest in Miss Blackerby and the unwanted results of that interest:

\section{DEAR PHILLIPS,}

You have, indeed, reason to be surprised, that I should have concealed my correspondence with miss Blackerby from you, to whom I disclosed all my other connexions of that nature; but the truth is, I never dreamed of any such commerce, till your last informed me, that it had produced something which could not be much longer concealed. It is a lucky circumstance, however, that her reputation will not suffer any detriment, but rather derive advantage from the discovery; which will prove, at least, that it is not quite so rotten as most people imagined - For my own part, I declare to you, in all the sincerity of friendship, that, far from having any amorous intercourse with the object in question, I never had the least acquaintance with her person; but, if she is really in the condition you describe, I suspect Mansel to be at the bottom of the whole ${ }^{3}$.

\footnotetext{
2 See Eliza Haywood, The Adventures of Miss Betsy Thoughtless, in Project Gutenberg, 2014, https://www.gutenberg.org/files/46346/46346-h/46346-h.htm. Accessed December 20, 2020.

3 See Tobias Smollett, The Expedition of Humphry Clinker, in Project Gutenberg, 2016, http://www.gutenberg.org/files/2160/2160-h/2160-h.htm. Accessed December 20, 2020.
} 
As critic Joseph Bottum notices in his seminal article dedicated to the academic novel, "[t]o some extent, the modern academic novel simply takes tropes and stock figures from the very beginnings of Western literature and places them on the contemporary college campus. The absent-minded professor and the stuffy pedant were comic staples before the birth of Christ" 4 . Bottom offers a concise history of the academic novel ${ }^{5}$ and also makes a differentiation between the British and the American form of this genre:

The British form of the academic novel has always tended to the traditionalist complaint of a lost collegiate Eden [...], while the American form tends more to the radical charge of an old-fashioned institution undone by its corrupt ways [...]. But the most curious thing about the entire contemporary genre is that it is produced exclusively by college professors who, whether from the right or the left, attack the intellectual world with a remorselessness and irony never seen before ${ }^{6}$.

The conclusion is that the academic/ campus novel is a depleted genre, an exhausted resource for writing, at least in the Anglo-Saxon countries. In her article on the twentieth century British novel, Angela Hague notices the importance of the campus as a literary topos and also the feeling of anger which announces the Angry Young Men of the Albion ${ }^{7}$. The campus novel has been analysed and/ or inventoried by several critics among whom mention must be made of Mortimer Robinson Proctor, John O. Lyons, John E. Kramer, David Bevan, Ian Carter, Robert F. Scott, Kenneth Womack, Elaine Showalter, Moseley Merritt, or Janice Rossen ${ }^{8}$. The ever increasing erosion of the academic prestige is emphasised by Martin Paul Eve who

\footnotetext{
4 Joseph Bottum, "The End of the Academic Novel", Washington Examiner, 9 August 1997, https://www.washingtonexaminer.com/weekly-standard/the-end-of-the-academic-novel. Accessed December 20, 2020.

${ }^{5}$ Ibidem: "The notion of writing a novel entirely about university faculty never occurred to anyone before 1950. When it did appear, however, the idea seemed to dawn on everyone all at once, and the '50s and early '60s saw a spate of stories about academic life".

${ }^{6}$ Ibidem.

7 Angela Hague, "Picaresque Structure and the Angry Young Novel", Twentieth Century Literature, 32, 1968, 2, pp. 209-220.

${ }^{8}$ Mortimer Robinson Proctor, The English University Novel, Berkeley, University of California Press, 1957; John O. Lyons, The College Novel in America. Preface by Harry T. Moore, Chicago, Southern Illinois University Press, 1962; John E. Kramer, The American College Novel. An Annotated Bibliography, Lanham, Scarecrow Press, 2003; David Bevan, University Fiction, Amsterdam, Rodopi, 1993; Ian Carter, Ancient Cultures of Conceit. British University Fiction in the Post War Years. London, Routledge, 1990; Robert F. Scott, "It's a Small World, after All: Assessing the Contemporary Campus Novel", The Journal of the Midwest Modern Language Association, 37, 2004, 1, pp. 81-87; Kenneth Womack, Postwar Academic Fiction. Satire, Ethics, Community, London, Palgrave Macmillan, 2002; Elaine Showalter, Faculty Towers: The Academic Novel and Its Discontents, Philadelphia, University of Pennsylvania Press, 2005; Moseley Merritt (ed.), The Academic Novel: New and Classic Essays, Chester, Chester Academic Press, 2007; Janice Rossen, The University in Modern Fiction. When Power Is Academic, New York, St. Martin's Press, 1993.
} 
admits that the contemporary novels he dealt with "exhibit an anxiety of academia" and discuss the "challenges of legitimation" 10 of this social subsystem.

The increasing number of universities which are viewed as a solution to many social problems and the way to the long dreamed status of middle class explains the popularity of the genre. Both readers and writers focus more and more on the academic milieus:

The most pragmatic reason for this attraction is rooted in the maxim 'write what you know.' With rise of MFAs, English departments, and labyrinthine literary theory in the twentieth century, many novelists have seized the opportunity and retreated into the ivory tower, where they can still manage to pay the rent in a technology-addled and paper-averse society ${ }^{11}$.

The scholarship on the campus novel is richer and richer. Robert F. Scott presents the state of the art in the criticism dedicated to the campus novel, while Jeffrey J. Williams tells the story of the campus novel and how it became a mainstream genre. After being "thought to be a marginal genre, perhaps with some exceptional moments like Mary McCarthy's Groves of Academe (1952), Kingsley Amis's Lucky Jim (1954), and David Lodge's Small World (1984), but otherwise quaint and eccentric, depicting the peculiar world of academics and appealing to a coterie audience" 12 , by the century's end the campus novel "had stepped out of the confines of so-called genre fiction by cross-pollinating with mainstream literary modes" 13 , such as satire, the thriller, the detective story or the Bildungsroman. David Lodge explains the campus novelists' proclivity towards satire and humour by the very peculiarities of the academic situations. The university professor is not some kind of godly servant offering sacrifices on the altar of "the disinterested pursuit of truth and the preservation of high culture"14.

On the contrary, the campus novel shows that higher education institutions are "staffed by human beings with ordinary human weaknesses and often more than ordinary eccentricities"15. Lodge's insistence on satire as a very suitable mode of the campus novel is not singular. John Kenny ${ }^{16}$, Mike Fischer ${ }^{17}$, the scholarly

\footnotetext{
${ }^{9}$ Martin Paul Eve, Literature against Criticism: University English and Contemporary Fiction in Conflict, Cambridge, Open Book Publisher, 2016, p. 46.

${ }^{10}$ Ibidem, p. 17

${ }^{11}$ Taylor Burgess, "A Genre in Discord: The Ubiquity of the Campus Novel”, Wide Angle. A Journal of Literature and Film, 3, 2013, 1, p. 60.

12 Jeffrey J. Williams, "The Rise of the Academic Novel", American Literary History, 24, 2012, 3, p. 561.

${ }^{13}$ Ibidem, p. 580.

14 David Lodge, "Nabokov and the Campus Novel", 24, Cycnos, 2008, 1, http://revel.unice.fr/cycnos/index.html?id=1081. Accessed December 20, 2020.

${ }^{15}$ Ibidem.

16 John Kenny, "Lampooning Academia in the Campus Novel", The Irish Times, 15 April 2006. https://www.irishtimes.com/news/lampooning-academia-in-the-campus-novel-1.1038980. Accessed December 20, 2021
} 
couple Mark Bosco and Kimberley Rae Connor ${ }^{18}$ follow suit. For instance, in "Fear and Laughing in Campus Literature: Contemporary Messages from a Comedic Tradition". the article authored by Katherine Reynolds, Robert Schwartz, and Beverly Bower, the campus novel is appreciated because "it acts more as a wakeup call than a call to arms concerning the peculiarities, sometimes absurdities of academic life" 19

Sally Dalton-Brown offers interesting consideration about the literary representation of the academic scholar:

Homo academicus is rarely a leader or inspirational teacher, as one might expect, but is very often depicted as a fool, fraud of philanderer imprisoned within a politically claustrophobic institution, and environment that almost appears to encourage foolishness, fakery, and philandering. The university... is something from which egress should, in fact, be sought if today's academic is to recover his ideals, but the academic who has fought for his place in that world understandably regards such an egress with ambiguity ${ }^{20}$.

One of the most ample studies on the campus novel is authored by Petr Anténe who has studied a large pool of campus novels published from the 1950's to the beginning of the $21^{\text {st }}$ century. The prevalence of satire in the campus novel shows awareness of the problems faced by the academia as well as optimism because the university "is both capable and worthy of reform" 21 . Taylor Burgess explains the campus novelists' appeal for satire by the importance of the flawed professor archetype. The academic is "a man or woman at the world's intellectual peak - but an impotent loser elsewhere" 22 .

Terminology hesitates between "academic novel" and "campus novel". According to Leuschner, the academic novel is an "offshoot of the campus novel" 23 which moved from the undergraduate student to the academics and the novel of tenure. New themes appear in the campus novel. The articles from the collection edited by Moseley Merritt discuss the appearance of new characters in the campus

17 Mike Fischer, "Adventures in Academia”, Milwaukee Journal Sentinel, 2010, https://archive.jsonline.com/entertainment/arts/101658423.html/. Accessed December 20, 2020.

${ }_{18}$ Mark Bosco, Kimberley Rae Connor, Academic Novels as Satire: Critical Studies as an Emerging Genre, Lewiston, Edwin Mellen Press, 2007.

${ }^{19}$ Katherine Reynolds, Robert Schwartz, Beverly Bower, "Fear and Laughing in Campus Literature: Contemporary Messages from a Comedic Tradition", The Journal of Educational Thought, 34, 2000, 1, p. 29.

${ }^{20}$ Sally Dalton-Brown, "Is There Life Outside of (the Genre of) the Campus Novel? The Academic Struggles to Find a Place in Today's World", The Journal of Popular Culture, 41, 2008, 4, p. 593.

21 Petr Anténe, Campus Novel Variations: A Comparative Study of an Anglo-American Genre, Olomouc, Palacky University Olomouc, 2015, p. 144.

22 Taylor Burgess, “A Genre in Discord”, p. 61.

${ }^{23}$ Eric Leuschner, "Body Damage: Dis-figuring the Academic in Academic Fiction", The Review of Education, Pedagogy, and Cultural Studies, 28, 2006, 3-4, p. 339. 
novels (the administrators, the cleaners), the marginalization of white males in the American academia, and the influence of political correctness upon academic life.

Syuzanna Poghosyan sums up several perspectives on the campus novel in a seminal article. She mentions that David Lodge distinguishes "two variations of academic novel. American university novel becomes known as a Campus novel, while the British variant is known as a Varsity novel" 24 . The former is mostly about the student-professor relationship, the latter is mainly about the student-student relationships. The interesting point is that in some campus novels "the university itself is described in detail and becomes a novel character" 25 . Poghosyan joins the numerous group of critics who talk about the importance of satire, irony, and laughter in this genre and she remarks that at present, "we see a tight mixture of satire and tragedy" 26 in campus novels. The characters are not very numerous and they are organized in opposing teams. Poghosyan considers that the main character is usually an intellectual who cannot adapt to society, the university being viewed as a haven and a protective space:

The hero is a very highly intellectual person and therefore finds it very difficult to fit into the uni-versity sphere. This is the reason why these characters are totally unable of co-exist-ing with the rest of the campus society. This hero does not see that he has chosen a wrong life path and it wears out his mental and physical strength ${ }^{27}$.

There is, however, in my opinion, an excess of anti-capitalist ideology in Poghosyan's evaluation of the academic as the main character. A much more convincing observation refers to the ever present ball or evening academic party

...which seems to be the peak when the tension tightens most. It makes possible to gather all the characters of the novel together and create all kinds of bonds among them. It is during this party that all the professional and personal conflicts reach their highest point ${ }^{28}$.

In spite of some slight ideological slippage, Poghosyan's article sums up very well the characteristics of the campus novel:

As a literary genre the academic novel has already got several concrete features, namely: the university as the corner stone of the novel; an evening party or ball which brings the novel to its climax; the unique type of hero; the opposing couples, which helps to increase the novel dynamics; ironic/ satiric mood of the narration ${ }^{29}$.

\footnotetext{
${ }^{24}$ Syuzanna Poghosyan, "The Characteristic Features of the Academic Fiction Genre”, Armenian Folia Anglistika, 8, 2012, 1-2, p. 139.

25 Ibidem, p. 141.

${ }^{26}$ Ibidem, p. 143.

${ }^{27}$ Ibidem.

${ }^{28}$ Ibidem.

${ }^{29}$ Ibidem, p. 144.
} 
American critics $^{30}$ have also paid attention to the problem of race in the campus novel. Although apparently, the increasing numbers of university recruitments from among ethnic minority students helps level social and economic disparities in American society, in fact the academia as a system reflects the racial divisiveness and inequality that exist out there in society. Findeisen notices that racial discrimination in the American academia and in college sports is denounced even from Elizabeth Stuart Phelps' novel Donald Marcy (published in 1893). The racial implications of the campus novel have also been discussed by Stephanie Brown ${ }^{31}$ and Lavelle Porter ${ }^{32}$. Both critics realize that the university campus can become a site for protest. Higher education has significantly contributed to increasing African American literary production and theoretical evaluation.

After the Clinton-Lewinsky scandal $(1998)^{33}$ sexuality on American campuses was discussed much more freely in literature, as well. As Jesse Kavadlo says, there was a "post-post-sexual revolution between male professors and female students" 34 in the American campus novel.

Recently the academic novel has been becoming global and by growing global it could not avoid regionalism. Significant in this respect are the articles authored by Rudolf Weiss (dealing with the academic novel in Germany and Austria) ${ }^{35}$, Prasanta Kumar Padhi (about the Indian academic novel) ${ }^{36}$ or Corina Selejan (about the Romanian campus novels). The problems of translating the American and the British campus novels into the languages and cultures with a different history of higher education also raise more and more academic interest. Marta Guirao, for instance, discusses the Spanish translations of David Lodge's campus novels in terms of generic and specific intertextuality. The former relies on the

\footnotetext{
${ }^{30}$ See Christopher Findeisen, "Injuries of Class: Mass Education and the American Campus Novel", PMLA, 130, 2015, 2, pp. 284-298.

${ }^{31}$ Stephanie Brown, "J. Saunders Redding and the African American Campus Novel", in The Postwar African American Novel: Protest and Discontent, 1945-1950, Jackson, University Press of Mississippi, 2011, pp. 132-160.

${ }^{32}$ Lavelle Porter, "The Overeducation of the Negro: On Reading Black Academic Fiction", in The Blackademic Life: Academic Fiction, Higher Education, and the Black Intellectual, Evanston, Northwestern University Press, 2020, pp. 15-44.

${ }_{33}$ President Bill Clinton and Monica Lewinski had a sexual relation between 1995 and 1997. The scandal broke out in 1998 and Clinton was impeached for having lied under oath about this episode in his life.

${ }^{34}$ Jesse Kavadlo, "Blue Angels Meet Dying Animals: Textual and Sexual Subversion in the Clinton-Era Academic Novel", The Journal of the Midwest Modern Language Association, 37, 2004, 2, p. 11.

${ }^{35}$ Rudolph Weiss, "From German to Austrian Academic Fiction: Regionalism Exponentiated", in Dieter Fuchs and Wojciech Klepuszewski (eds.), The Campus Novel: Regional or Global?, Leiden, Brill, 2019, pp. 93-108.

${ }^{36}$ Kumar Padhi Prasanta, "Indian Campus Novels: An Emerging Genre in Literary Writing", Journal of Humanities and Social Science, 22, 2017, 11, pp. 1-8.
} 
parodic discourse often encountered in this literary discourse, the latter on the revisitations of canonical texts in English literature ${ }^{37}$.

This new, based-on-globalization approach insists on the political agendas, the mental dispositions, and the distinctiveness of various academic systems from all over the world. The Western academic novel tries to rehabilitate the erotic in the academia in spite of the impositions of political correctness. At the same time, Sapphic passions and queer discourses knock at the door of visibility and public recognition.

The Romanian campus novel - or rather the Romanian academic novel because few Romanian universities have a single unitary campus like the American ones has a pretty rich history. Novels dedicated only to the academic life were published mostly after 1990. Reasons are multiple but an important factor is the relative youth of academic life in Romanian culture. Documents record the foundation and the activity of some higher education institutions founded on the territory of present-day Romania in the sixteenth century ${ }^{38}$, but they only had a short and intermittent academic life. The Romanians did not have universities in the eleventh century, such as the Italians in Bologna, or the English in Oxford.

Corina Selejan made a thorough inventory of the academic novels but the pre1990 span of time is not well represented in her research ${ }^{39}$. Selejan's studies could be enriched with some novels whose plot is wholly or, at least, partly connected to the university. Mention should be made of the academic novels presenting students' life during the communist regime, or more precisely the confrontation between authentic scholarship offered by some prestigious professors and the ideological and political impositions of the time. Some of the most convincing

${ }^{37}$ Marta Guirao, David Lodge's Campus Novels in Spanish Translation: A Comparative Study of Genre and Intertextuality. Unpublished Ph.D. thesis defended at the University of London, 2002, https://discovery.ucl.ac.uk/id/eprint/1382487/. Accessed December 20, 2020.

${ }^{38}$ Schola Latina founded by Despot Vodă at Cotnari or the Jesuit College from Cluj.

${ }^{39}$ Corina Selejan mentions the following novels in her 2019 studies (“"How to Save Difference': Contemporary Romanian, German, English and American Academic Novels" in Dieter Fuchs and Vojciech Klepuszwski, (eds.), The Campus Novel: Regional or Global?, Leiden, Brill, 2019, pp. 166179; "The Romanian Academic Novel and Film through the Postcommunism/ Postcolonialism Lens", Polish Journal of English Studies, 2019, 2, pp. 87-102): Ion Vianu, Amor Intellectualis. Amorul unei educaţii [Amor Intellectualis. The Love Story of Some Education] (2010); Oana Tănase, Filo, Meserie! [Faculty of Letters, Cool!'] (2005); Alexandru Muşina, Nepotul lui Dracula [Dracula's Descendant] (2012); Andrei Bodiu, Bulevardul eroilor [The Heroes' Boulevard] (2004); Caius Dobrescu, Teza de doctorat [The Ph.D. Thesis] (2007) and Minoic [Minoan] (2011); Lucian Bâgiu, Bestiar: Salată orientală cu universitari închipuiți [Bestiary: Oriental Salad with Presumptuous Academics] (2008); Gabriela Gavril, Fiecare cu Budapesta lui [Everyone Has His Own Budapest] (2007); Ovidiu Pecican, Noaptea soarelui răsare [The Night of the Rising Sun] (2014); Anton Marin, Eu, gândacul [I, the Bug] (2009); Radu Vancu, Transparenţa [Transparency] (2018). The only interwar academic novel inventoried by Selejan is Zilele și nopțile unui student intârziat [A Belated Student's Days and Nights] (1930) by Gib I. Mihăescu and the only novel, mentioned by Selejan, which also describes academic life under the communist regime is Cearta [The Squabble] (1969) by Al. Piru. 
novels in this group are: Pop Simion's Student la istorie [A History Student] (1985), Teofil Buşecan's Paranteze [Parentheses] (1967), Constantin Cubleşan's Licheni [Lichens] (1974), Eugen Zehan's Studenţii [Students] (1977).

Very few Romanian academic novels are authored by women and this is no wonder as the Romanian university widely remained a predominantly male territory up to the Communist period. Marta Rădulescu, one of the few women authoring an academic novel before 1948, announced another academic novel Cadavre, roman din viaţa universitară [Corpses. A Novel from the Academic Life] in 1933, when she published Sînt studentă! Reportagii fanteziste [I Am a Student! Imaginary Reportages]. Unfortunately, this project never became a reality. When they do write about the Romanian academia, female novelists ${ }^{40}$ insist on the emotional side of academic life: the provincial female students' brutal insertion into the big city, the sexual and the emotional consequences of the female students' relationships with the gatekeepers of academic life (the male professor viewed as a mentor, a father figure, and a potential lover).

The Romanian academic novel has also been influenced by the tortuous history of the Romanian state during the twentieth century. Borders changed, territories were incorporated into the Romanian state or passed under the authority of neighbouring states. This influenced academic life: universities had to take refuge on territories allowed to remain under the authority of the Romanian state; young people from the new Romanian provinces were offered new academic options within the new Romanian borders. Examples in this respect are Ionel Brandabur's Un student de altădată [An Olden Times Student] (1987) and Ioan Sulacov's Studentul din Bugeac [The Student from Bugeac] (1935). The former presents the academic life of the University of Cluj that had to take refuge to Sibiu in 1940 when the north-western part of Transylvania entered within the boundaries of Hungary after the Vienna Award. The latter presents the story of a poor student from Bugeac, a territory that was incorporated into Romania after World War I and which previously had been part of the Tsarist Empire. The plot of the Romanian academic novel often relies on love stories that failed because of religious ${ }^{41}$, ethnic $^{42}$, or class differences ${ }^{43}$. Studentship is a period in one's life that coincides with Romantic ardour and brave challenges of societal stereotypes and prejudice.

Olga Caba, a former student of the Faculty of Letters in Cluj, who benefited from a scholarship in Scotland during the interwar period, wrote the first novel that announces a quite frequent theme in the post-1990 Romanian academic novel: the

\footnotetext{
${ }^{40}$ Some of the best such novels are authored by Sanda Movilă (Desfiguraţii [The Disfigured], 1935) and Lucreţia Petrescu (Mărăcini [Thistles], 1937).

${ }^{41}$ Otrava [The Poison] (1940) by Emil Dorian is the love story of a Christian student (Radu Socoliu) and a Jewish one (Frida Bălan).

42 Supravietuitorii [Survivors] (1980) by Marta Cozmin tells the tragic romance between Fabian Vladimir, a student in Philology, and Maria, a Gypsy adolescent.

${ }^{43}$ In Cora. Istoria unei iubiri naive [Cora. A Naïve Love Story] (1977) by Virgil Duda.
} 
Romanian student studying abroad and confronting different academic and societal mores $^{44}$.

For the present analysis of the Romanian academic novel, I have chosen three such fictions: Marta Rădulescu's Sînt studentă! Reportagii fanteziste [I Am a Student! Imaginary Reportages], published in 1933; Alexandru Muşina's Nepotul lui Dracula [Dracula's Descendant], published in 2012; and Codrin Liviu Cutitaru's Scriptor sau Cartea transformărilor admirabile [The Scriptor or the Book of Admirable Transformations], published in 2017. Rădulescu's novel can point to the peculiarities of female authored academic novels and during the interwar period, Muşina skilfully mixed an ironical treatment of Dracula's theme with the description of the Romanian academia in the 1990s, whereas Cutitaru's novel is a good example of a metafictional academic novel.

Marta Rădulescu's book Sînt studentă! [I Am a Student!] has a subtitle Reportagii fanteziste [Imaginary Reportages] which does not correspond to the actual form of the book, although some fragmentarism does exist. In my opinion, this subtitle is meant to protect the author from potential critiques that she dared to approach such a difficult and prestigious literary form as the novel. On the other hand, this subtitle insists on the veracity of the representation of the Romanian academic life and offers Rădulescu protection from the "sovereigns" of academic life that might recognize themselves in this book. In both cases, Rădulescu's awareness that she wrote in a patriarchal milieu is obvious. The novel presents with humour and realism the integration into the university of a young female student who has literary ambitions and is the daughter of a university professor. The fact that the title character belongs to the university elite by the very reality of her birth is of significant importance. As Lucian Nastasă pointed out in his researches ${ }^{45}$, the Romanian academia delights in cultivating academic dynasties and meritocracy is certainly not encouraged enough.

Rădulescu's academic novel has been accused of superficiality and the author did not benefit of too much attention from Romanian critics. Aurel Sasu, the author of the entry on Rădulescu's academic novel in Dicţionarul cronologic al romanului românesc de la origini până la 1989 [The Chronological Dictionary of the Romanian Novel from Its Origins to 1989] (DCRR), considers this fiction ,a very funny documentary" ${ }^{\prime 6}$. Carmen Brăgaru, the author of the entry on Marta

\footnotetext{
${ }^{44}$ Cumpăna din cetate [The Scale from the Fortress] by Olga Caba.

${ }^{45}$ See Lucian Nastasă, Intimitatea amfiteatrelor. Ipostaze din viaţa universitarilor "literari" (18641948) [The Intimacy of Amphitheatres. Faces in the Privacy of the "Literary" University Professors (1864-1948)], Cluj-Napoca, Limes, 2010, and Lucian Nastasă, "Suveranii" universităţilor româneşti. Mecanisme de selecţie şi promovare a elitei intelectuale [The "Sovereigns" of Romanian Universities. Intellectual Elites' Mechanisms of Selection and Promotion], Cluj-Napoca, Limes, 2007. ${ }^{46}$ See Dicţionarul cronologic al romanului românesc de la origini până la 1989 [The Chronological Dictionary of the Romanian Novel from Its Origins to 1989], București, Editura Academiei Române, 2004, p. 305: "foarte amuzant documentar". The Romanian quotations have been translated by Mihaela Mudure.
} 
Rădulescu in Dicţionarul general al literaturii române [The General Dictionary of Romanian Literature] considers that this novel contains only "satirical sketches and caricatures that cannot be more than mere reproductions of reality with no real attempt at artistic rendering" ${ }^{47}$. And, finally, Mariana Vartic, the author of the entry on the same topic in the well-known Mircea Zaciu, Marian Papahagi, and Aurel Sasu's Dictionary also belittles Rădulescu's novel as a collection of "easy-going sketches" ${ }^{\prime 4}$.

An important target of Rădulescu's satire is the academic establishment. The author is merciless and demanding. Mercantile, narrow-minded, arrogant, most of the academics rather offer their students models of what one should not do than what one should do. Some caricature portraits retain the reader's attention. The dean is "a scrawny gentleman, bald, with a handlebar moustache, and a brown beard like a mason's brush eaten by moths" 49 , Professor Preda Neicu-Bostan is "an old and fat gentleman looking like a huge and apocalyptic pug puppy"50. There is quite a lot of violence on the corridors of the university. The Dean slaps a male student because he does not give up his place to the female students queuing up to pay their exam fees. In fact, the male student was queuing instead of a female student. When the situation is clarified, the Dean leaves the building as furious as he entered. Now he is angry because proven wrong. Rădulescu has a keen eye for all the actions of the academic autocracy. The university is depicted as a bureaucratic system that functions for its own sake and reproduction. The students' interests and concerns are certainly no priority. "The schedule is mobile, incoherent like an ice floe when it melts" ${ }^{51}$. Few professors offer support materials for their courses and students have to rely on their notes which they share according to the fidelity networks they belong to: "Gina and Tina are at their desk, they are about to finish transcribing notes, copying from their notebooks and from their classmates', compiling the valuable documents, feverishly deciphering the sibylic texts..."52.

Apparently, the purpose of the higher education institution is to produce graduates that would contribute to the development of society. In fact, the

47 See Eugen Simion (ed.), Dicţionarul general al literaturii române [The General Dictionary of Romanian Literature], P-R, București, Univers Enciclopedic, 2006, p. 533: "schiţe satirice şi caricaturi ce nu pot depăşi nivelul de copiere a realităţii fără nicio tentativă de transfigurare artistică". 48 See Mircea Zaciu, Marian Papahagi, Aurel Sasu (eds.), Dicţionarul scriitorilor români [The Dictionary of the Romanian Writers], R-Z, București, Albatros, 2002, p. 33: "schiţe uşoare".

${ }^{49}$ Marta Rădulescu, Sînt studentă!. Reportagii fanteziste [I Am a Student! Imaginary Reportages], București, Editura "Adevărul”, 1933, p. 21: "[u]n domn deşirat, chel,cu mustăţile pe găleată, o bărbuţă pământie ca o bidinea mâncată de molii”"

${ }^{50}$ Ibidem, p. 23: "un domn bătrân şi gros aducând a un uriaş făt de mops apocaliptic".

51 Ibidem, p. 19: "Programul e mobil, incoerent ca un zăpor de sloiuri în vremea dezgheţului. Cursurile se-ncalecă şi coincid, se ciocnesc cap în cap; profesorii schimbă orele, lipsesc când se anunţă şi vin când nu-i aştepţi”".

52 Ibidem, p. 187: “Gina şi Tina, la birou, sfârşesc de transcris caiete de notiţe, copiind din maculatoarele lor şi din ale colegelor, compulsând preţioasele documente, tălmăcind cu înfrigurare textele sibiline...". 
university is very much a mercantile institution. Some professors fail students because they receive a quota of the exam fees paid by students. In this way, the faculty provide for themselves a new source of income during the exam period. "He failed us all so that he can take the examination fees again, in the autumn" 53 . The complaining female students form "the maenads" choir" ${ }^{54}$. (Charming irony showing acquaintance with classical mythology!)

Rădulescu's approach to the academic novel combines social critique with humour and satire. The novelist insists on the hardships of poor students who fight hard to pursue academic studies and hope to improve their social status after graduation. A painful example hovering on tragedy is Valerica, an orphan student who has no scholarship and has to battle with the financial difficulties of academic life. She has no other option but to toil for Aunt Filofteia, "the wife of Pleşu, undermanager at the Treasure Bank" 55 in exchange for accommodation. Rădulescu skilfully makes tragedy alternate with humorous episodes. Students are required to audit long and boring lectures they are not interested in. The students' final clappings are in direct proportion with their joy that the lecture is over:

The soft snoring in front of me makes me bend over my desk: the gentleman on my left is sleeping, his mouth agape, his head slightly bent sideways. He seems to be under a tree, in the shade. He is waking up only at a quarter to one during the audience's clapping. We are slapping our palms, making the blood circulate by applauding with animalistic satisfaction ${ }^{56}$.

Eroticism is an important component of the Romanian academic life. Rădulescu is both emotional and sarcastic when she reaches this territory. The reader is impressed by the tragic love story between two students: Mircea Sorescu and Ana Petreanu. Mircea suffers from an incurable disease but he stubbornly continues to come to school. In the end, Ana's pure love will bring Mircea emotional comfort and he can die in peace. On the other hand, in this world dominated by the patriarchal professor who is practically accountable to no one, some students try to use old strategies that the patriarchy not only accepts but it also condones. Representative is "Venera Stoican, an attractive brunette who flirts with everybody: from the janitor to the Dean"57. The university is intensely hierarchical. Women can be secretaries or cleaners or laboratory workers, but there are no female professors. The staff's hierarchy is reproduced among the students.

\footnotetext{
${ }^{53}$ Ibidem, p. 166: "Ne-a trântit pe toate ca să mai ia un rând de taxe la toamnă".

${ }^{54}$ Ibidem, p. 166: "corul menadelor".

${ }^{55}$ Ibidem, p. 88: "nevasta lui domnul subdirector Pleşu de la banca Comoara".

56 Ibidem, p. 48: "Un sforăit lin înaintea mea mă face să mă aplec peste bancă: domnul din stânga doarme cu gura larg căscată, cu capul uşor plecat într-o parte. Parcă ar fi sub un pom, la umbră. Nu se deşteaptă decât la unu şi un sfert în ropotul aplauzelor. Ne dezmorţim palmele, punem sângele în circulaţie aplaudând cu animalică satisfacţie".

${ }^{57}$ Ibidem, p. 163: "Venera Stoican, o brunetă frumuşică şi care flirtează cu toată lumea: de la portar până la Decan”.
} 
Those who have reached "the third year's Olympus" 58 look down on their colleagues who still have to pass through the rituals of many exams. Rădulescu's academic novel contains an interesting metaleptic note. The border between fiction and reality is sometimes crossed by the narrator who dares to describe the reality of Romanian schooling and considers truth a narratological duty: "You describe the egghead factory and stupidity sprawling like a polenta of academic life, to the extent that you know it" ${ }^{\prime 59}$. But the narrator is about to pay a heavy price for her courage. She is considered a whistle blower that it is better to avoid: "Fink makes a wry face at me, professors do not seem to hear my greeting, most of the friends I had before my book came out, turn their back on me or pretend that they do not see me anymore. Pepi, Asineta et comp. do not visit me anymore" 60 .

Rădulescu uses a students' strike in order to point to many of the problems Romanian higher education had before the communist inspired reform of 1948. Teachers are practically not accountable and grade according to highly subjective scales, exams schedules are optional, students have no say in the academia, many students are confronted with serious economic problems and they are not supported by the university at all.

Rădulescu makes her novel end with a meeting between the narrator and two of her colleagues who are politically involved. One is a Communist, the other sympathizes with Corneliu Zelea Codreanu's fascist movement. Published in 1933, Marta Rădulescu's academic novel catches very well the fears of that time and foreshadows the victory of leftist totalitarism. The students who have already made their political options put on airs and display a somehow maternal attitude towards the narrator who feels she is at an existential and political crossroads: "The two women are looking at me like two smiling sphinxes, at the gate of a new world that I do not understand and I fear" 61 . This conversation takes place against a background that discreetly foreshadows the course history will take. "From the hill to the barracks, the evening trumpet is sounding long and sad, as if it hesitated against the red sunset"62. The narrator's reservations are evident but it is the end of a historical cycle. Blood, intransigent ideologies and red flags loom beyond the horizon.

Rădulescu's knack for social critique is continued at a distance of several decades by Alexandru Muşina who is lucky enough to write after the reversal of

\footnotetext{
${ }^{58}$ Ibidem, p. 163: "Olimpul anului trei".

59 Ibidem, p. 203: "Descrii fabrica de belferi şi prostia lăbărţată ca o mămăligă a vieţii universitare atâta cât o cunoşti".

${ }^{60}$ Ibidem, p. 128: "Fink se uită urât, profesorii nu-mi mai răspund la salut, marea majoritate a prieteniilor anterioare cărţii, îmi întorc spatele sau se fac că nu mă văd. Pepi, Asineta et comp. nu mai dau pe la mine".

${ }^{61}$ Ibidem, p. 210: "Cele două femei mă privesc ca doi sfincşi zâmbitori, la poarta unei lumi noi, pe care n-o înţeleg şi de care mi-e teamă”.

${ }^{62}$ Ibidem, p. 210: "Din deal, de la cazarmă, goarna de seară sună prelung şi trist, ezitând parcă în crepusculul roşu".
} 
the communist dictatorial regime. His novel Nepotul lui Dracula combines several literary formulas (the academic novel, the gothic novel) in a very successful parody where the new discourses imported from the West after 1990 are satirized with zest and talent. Nor does the West escape from Muşina's scathing satire. Dracula and the Gypsies (Roma) are the West's favourite tropes in the representation of Romania. Muşina offers such potential readers what they want while also mocking at their haughty limitations. The title character of Muşina's novel, Florin Angelescu Dragolea, a Proust scholar who is assistant professor at a university in Braşov, finds out that, in fact, he is a descendant of Vlad the Impaler. Dragolea suffers, like his ancestors, from a very rare medical condition which requires that he drinks a full cup of human blood every day. Because of lack of fresh human blood and the harmful influence of the environment, Dragolea's pathology becomes much more complex. He "suffers from a serious form of postmarital delirium tremens and collateral amnesia due to unhealthy food lacking blood and heavy smoking - 21-36 cigarettes per day - plus repeated Proustian semiosis, and CFL seminars ${ }^{63}$. He completely forgot his roots and his ancestors" ${ }^{\prime 64}$.

The academic plot is spiced with Gothic elements, a subplot inspired from Romanian national history, and with critical realism when postcommunist realities are depicted. Florin's ancestors used to get their bloody drink from a family of Gypsy slaves, the Boboieri, who come to commercialize their extra-healthy blood in post-1990 Germany. Corina Selejan gives a short, but very accurate characterization of the academic plot in Muşina's Nepotul lui Dracula: "Academic dishonesty and corruption in the university are constant concerns in Muşina's relentlessly parodic novel" ${ }^{15}$. Academic life is characterized by lawlessness. Regulations exist but they are not followed:

With us, the professor is royalty, he teaches what he wants and how he wants. The curriculum posted on the university site does not matter. The only problem is that nobody should complain. And nobody complains. On the one hand, because students do not read what is on the university site. On the other hand, because it is only those

\footnotetext{
${ }^{63}$ Contemporary French Language.

${ }^{64}$ Alexandru Mușina, Nepotul lui Dracula [Dracula's Descendant], Braşov, Aula, 2012, p. 206: "suferă de o formă gravă de delirium tremens postmarital şi de amnezie colaterală, datorită alimentaţiei nesănătoase, fără sânge, dar şi consumului excesiv de ţigări, 21-36 pe zi, plus semioză proustiană repetată şi seminarii de LFC. Şi-a uitat complect rădăcinile şi strămoşii”.

${ }^{65}$ Corina Selejan, "The Romanian Academic Novel", p. 98. Selejan's article is a very careful reading of Muşina's novel, an example of good quality scholarship. There is, however, one questionable statement in this article. When referring to the secretary of the university, Enikö Trăistaru, Selejan mentions that Trăistaru is "a former Securitate member who is also a woman, an ethnic Hungarian and a Protestant in a predominantly Orthodox country - apparently, the quintessence of the minority status - is revealed to be the school's true director, exceeding the Dean in power". The reader can easily understand that the "quintessence of the minority status" in Romania is to be a former Securitate member and have some kind of secret power over the academic community from the fictional Braşov.
} 
who do not get their degree who write complaints. But this never happens: Romanian universities need students, as many students as possible, because their public funding depends on the number of students they have enrolled ${ }^{66}$.

The academic system is a perverse instrument that replaces authentic genuine knowledge and culture, and skills with a make-believe degree that will finally endanger the whole society. The narrator notices with bitterness: "our students do not need knowledge, but high grades and a degree" $" 67$.

Academic discourses roll in a cascade and they are all submitted to Muşina's satirical arrow. The terminological incontinence reminds one of Rabelais and his satire of the pedantic and useless "knowledge" bestowed by medieval Sorbonne upon its addicts. The book abounds in picturesque descriptions of the students' bodies and interests. Most of them, samples of the male gaze:

Jenny was a real Valkyrie, one point eight metres tall, thick and curly hair, like a flame, green eyes, fair complexion, discreetly freckled and a superb body, she used to be a volleyball player [...] she was a high breed erotic panther, a sweet and permanent danger for any male aged between 15 and $75^{68}$.

Academic rituals of passage, pilgrimages to the academic shrines of the annual or bi-annual conferences are described with a unique mixture of seriousness, scholarly competence, and indulgent smile. Dragolea goes to Sibiu to attend a colloquium on Lucian Blaga:

He paced slowly towards the Faculty of Letters, History, Philosophy, Psychology and Theatre where the last section of the colloquium took place. He could not miss that as 'the great ones' were to read their papers: our colleague, Priest Professor Claudiu Ţărmure, the star of Blaga ${ }^{69}$ studies, Professor Wolfgang Năpristoc from Timişoara, Professor Leonida Meiroşu from Iaşi, Professor Flavius Constant Cotoşman from Cluj. But also the lady professors: Rustem Seitabla Ibrahim Fatih from Constanţa, Ecaterina Morcov Dăbuleanu from Sibiu, and, of course, Aliona Verbinski Simionescu, a semiotician of European renown ${ }^{70}$.

${ }^{66}$ Alexandru Muşina, Nepotul lui Dracula, p. 6: "La noi profesorul e rege, predă ce şi cum vrea el. Nu contează ce scrie în programa afişată pe site-ul universităţii. Totul e ca nimeni să nu facă reclamaţii. Şi nimeni nu face reclamaţii. Pe de o parte, fiindcă studenţii nu citesc site-ul universităţii. Pe de altă parte, pentru că reclamaţii nu fac decât cei care nu reuşesc să-şi finalizeze studiile. Dar asta nu se întâmplă niciodată: universităţile din România au nevoie de studenţi, cât mai mulţi studenţi, fiindcă statul le finanţează în funcţie de numărul acestora".

${ }^{67}$ Ibidem, p. 351: "studenţii noştri nu au nevoie de cunoştinţe, ci de note mari şi de o diplomă".

68 Ibidem, p. 29: "Jenny era o adevărată walkirie: înaltă de un metru şi optzeci, cu păr bogat şi cârlionţat, ca o flacără, ochi verzi, ten alb, discret pistruiat şi un corp superb, de fostă voleibalistă [...] era o panteră erotică pur sânge, o dulce şi permanentă primejdie pentru orice bărbat între 15 şi 75 de ani".

${ }^{69}$ Lucian Blaga (1895-1961), one of the greatest Romanian poets.

70 Ibidem, pp. 191-192: "[A] pornit încet spre Facultatea de Litere, Istorie, Filosofie, Psihologie şi Artă Dramatică, unde se ţinea ultima sesiune a colocviului. Nu putea în niciun caz să lipsească, mai ales că urmau să se producă 'greii': colegul nostru, preotul profesor Claudiu Ţărmure, starul studiilor 
Such academic events always end with a party where participants can socialize and build future academic networks, make or destroy alliances. A hierarchical etiquette is strictly followed. Dragolea listens with religiosity to the personalities present, then he pays some compliments on their academic achievements to the most important participants: "Professor Țărmure, our colleague from Braşov, as well as Professors Ternian, Moşmondea, and Ghiţulete, the main organizers of the colloquium" $"$.

The academic world is populated with an interesting fauna among which the Pentagon, a group of the best professors in the Faculty, all males, of course, who meet periodically in order to have highbrow conversations and gossip at a high academic level. Here they are: "the fierce Cosiga, [...] the handsome Cruceru, the Ice Eyed, [...] scholar Darius Stroescu, or the alluring Dean Miky Banciu""72; "Professor Vasile Peteanu, a comparatist and phenomenologist [...] plus Andy Cruceanu, the new rising star of the Faculty" "73.

Muşina is second to none in describing the arcane relations between the members of the academic community of fictional Braşov. Spying, secret alliances, harsh or mild animosities consolidate the academic pyramid. Female colleagues are either boring and hard working or intrigant and shallow intellectuals. Mention is made of: "Andrada Bergovici, the assistant and informant of Marilena Bularca Tuchilatu, the head of the English teaching faculty"74; "Veronica Cîmpeanu, a young Blaga female scholar and Romanian literature lecturer at the University of Baia Mare" 75 .

If in Rădulescu's academic novel, the university men are re-presented as members of a privileged caste that rules, practically unchallenged, over a very important activity in any society: the formation of the future elites; communism certainly contributed to the erosion of this reality. Muşina's academics bitterly talk about their numerous chores and the chains imposed upon them by the so-called "audit university", an invention of the post-modernist economists in alliance with politicians responsible for public policies in post-1990 education. The university is

blagiene, profesorul Wolfgang Năpristoc de la Timişoara, profesorul Leonida Meiroşu de la Iaşi, profesorul Flavius Constant Cotoşman de la Cluj. Dar şi doamnele Rustem Seitabla Ibrahim Fatih, de la Constanţa, Ecaterina Morcov Dăbuleanu, de la Sibiu, şi, desigur, Aliona Verbinski Simionescu, semiotician de renume european".

71 Ibidem, p. 199: "profesorului Ţărmure, colegul nostru de la Braşov, şi profesorilor Ternian, Moşmondea şi Ghiţulete, principalii organizatori ai colocviului".

72 Ibidem, p. 61: "teribilul Cosiga, [...] frumosul Cruceru, cel cu ochi de gheaţă, [...] savantul Darius Stroescu sau şarmantul decan Miky Banciu".

73 Ibidem, p. 105-106: "profesorul Vasile Peteanu, comparatist şi fenomenolog [...] plus Andy Cruceanu, noua stea în ascensiune a facultăţii".

${ }^{74}$ Ibidem, p. 110: "Andrada Bergovici, asistenta şi informatoarea Marilenei Bularca Tuchilatu, şefa colectivului de engleză".

75 Ibidem, p. 211: "Veronica Cîmpeanu, jună blagoloagă şi lectoriţă de literatură română la Universitatea din Baia Mare". 
no longer primarily an institution offering knowledge and education but a kind of factory whose efficient assembly line must bring financial profit. Many Romanian academics would recognize their own duties in this acerbic picture of Muşina's academics. What are their responsibilities?

Two teaching loads for a pitiful salary, checking thousands of applications for a so-called admission at the university, making documents - hundreds of pages - for the so-called evaluations and accreditations. They [the faculty] are to be blamed if students play hooky and do not study, but one cannot fail them for we run out of customers and we get no more money for our salaries ${ }^{76}$.

A character specific to the Romanian academic world is the scholar incapable of finalizing his doctoral thesis. Procrastination combines with his incapacity to concentrate on a specific topic. On the other hand, the institution also procrastinates to fire Remus Durac and enforce the legislation extant. Once one gets into the system, he can be demoted but firing is postponed again and again. The Balkan lassitude can be easily recognized here. Initially, Remus Durac works on a thesis entitled The Semiosis of Hoax in the Romanian Folk Stories ${ }^{77}$ under the competent supervision of Professor Verbinski Simionescu. Eight years have passed and Durac still does not defend his thesis. He enrols in a new doctoral programme working on The Semiosis of the Identity Anguish with Emil Cioran and Paul $\mathrm{Celan}^{78}$ at the University of Cluj, under the equally competent supervision of Professor Ernest Sîmboteanu. Still, he cannot finalize this thesis either and in 2003 he enrolled in another new doctoral program with the thesis entitled Identity and Persecution in Zaharia Stancu's Novel "The Gypsy Tribe"79 under the supervision of Professor Dorian Suru. Colleagues bet whether Durac will finalize his thesis or not, but nobody thinks that he should be fired and an end should be put to this never ending story. "Everybody was looking forward to see when and if he would defend his doctoral thesis. People even made bets: would he succeed or not this third time? The only one who did not care at all was Remus himself" ${ }^{\prime 80}$.

Eroticism bathes the whole academic atmosphere. The admiration of the students (overwhelmingly female students) for their professors hovers on physicality. The academic audience is represented as a female in heat and only humour - truly excellent quality humour - saves Muşina from misogynism. While

\footnotetext{
${ }^{76}$ Ibidem, p. 141: "De făcut norme duble, pe un salariu de râsul curcilor, de verificat mii de dosare pentru o aşa-zisă admitere şi de făcut alte dosare, de sute de pagini, pentru aşa-zise evaluări şi acreditări. Responsabili că studenţii chiulesc şi nu învaţă, dar nu-i poţi pica, că rămânem fără muşterii şi pierdem banii de salarii”".

77 Ibidem, p. 201: Semioza păcălelii în snoavele populare româneşti.

${ }^{78}$ Ibidem, p. 202: Semioza angoasei identităţii la Emil Cioran şi Paul Celan.

${ }^{79}$ Ibidem, p. 202: Identitate şi persecuţie în romanul "Şatra" de Zaharia Stancu.

${ }^{80}$ Ibidem, p. 202: "Toată lumea aştepta cu sufletul la gură să vadă când şi dacă îşi va susţine, totuşi, teza. S-au făcut chiar pariuri: va reuşi sau nu din a treia încercare? Singurul care nu-şi făcea nicio problemă era chiar Remus".
} 
Dragolea was lecturing, the female students "tried to pierce the ice stratum of his impeccable French, his armour of semiotic concepts, his mail shirt of masterly wordings and quotations from the titans of semiotic thought and not only ${ }^{81}$.

Some of the male academics do respond to these efforts. An interesting sample is Remus Durac, whose constantly growing rhizomic network of female acquaintances point to his privileged position as a man who is a teacher and university professor. Adoring Durac coincides, up to a point, with climbing one or maybe even several steps of the academic hierarchy. Remus Durac "[w]as on a rhizomic quest, Woman in, from, and through women. [...] Unlike others, Remus did not attend colloquia or conferences in order to collect academic points but to begin or resume new and ever new amours" $" 82$.

There is, therefore, in Mușina's novel an inherent narratorial conviction that the male perspective is one and the same with the human perspective. Woman is some kind of deviation from the generic human:

Women like to talk a lot, they like to verbalize, for them 'parole' is much more important that 'langue', they are not really interested in the profound semiotic structure of communication and its complex relationship to the real contingency. They do not fully realize the consequences, the meanders, and the dangers of the metaverbal concreteness. Their semiosis is always superficial and limited to the present. Wonderful and necessary, in their own way, women have another semiotic understanding of the world, which is also necessary but insufficient. Women are women. Men are $\operatorname{men}^{83}$.

Partly jokingly, partly seriously Muşina's discourse dangerously hovers on militant misogynism but satire, humour, parody combine and save the novel.

A peculiarity of the Romanian academic novel is its constant reference to foreign academia. The foreign lecturer, whether sent by DAAD, British Council, Alliance Française, or the Fulbright Commission, is the embodiment of foreign culture, foreign wealth, foreign superiority. Muşina's novel also includes a subplot about the battle for the conquest of the foreign lecturer sent to the fictional university of Braşov. Jennifer Leontovici is the winner of this harsh competition

81 Ibidem, p. 62: “încercau să străpungă stratul de gheaţă al francezei lui impecabile, blindajul de concepte semiotice, cămaşa de zale de formulări măiastre şi citate din titanii gândirii semiotice, şi nu numai".

${ }^{82}$ Ibidem, p. 199: “[c]ăuta rizomatic, Femeia în, din, şi prin femei. [...] Remus nu participa la colocvii sau sesiuni de comunicări ştiinţifice ca alţii, pentru a aduna puncte academice, ci pentru a înnoda, sau reînnoda, noi şi noi amoruri".

83 Ibidem, p. 244: "Femeile vorbesc mult, le place să verbalizeze, pentru ele 'parole' e mai importantă decât 'langue', nu le interesează cu adevărat structura semiotică profundă a comunicării şi complexitatea relaţiei acesteia cu realul contingent. $\mathrm{Nu}$ gândesc până la capăt toate consecinţele, meandrele şi primejdiile concretului metaverbal. Semioza lor e întotdeauna superficială, limitată la prezent. Minunate şi necesare, în felul lor, femeile au altă înţelegere semiotică a lumii, legitimă şi ea, dar insuficientă. Femeile sunt femei. Bărbaţii sunt bărbaţi”. 
and the narrator deplores, in elegiac lines, the dire fate that awaits for Mathew [sic] McDuck, the Scottish lecturer sent by the British Council:

Alas, Mathew, Mathew, poor Englishman, poor Scotsman, stingy, wandering in the twilight of your life on Mioritza's land ${ }^{84}$, both unforeseen pleasures and reckless expenses, and unimaginable sufferings are awaiting for you! Jennifer is like a fire scorching everything around, a panther from the selva oscura of the mysterious East [...] Mathew, Mathew, poor Englishman, poor Scotsman, stingy, taken by the wave of Jennifer's pheromones, dire days are awaiting for you, lots of money you will spend and many tears you will shed! [...] But who and how could advise him, who should teach him what to do as he was the messenger sent by the British Council to show us, the Romanians from this edge of Europe, what and how think and do in order to get civilized $?^{85}$.

Muşina's academic humour extends to the neo-colonialism of European Union, a soft version of former imperialisms. Plus ça change, plus ça reste la même chose! Empires come and go; laughter and humour continue to be the let-go and the revenge of the subaltern.

Muşina's novel ends in a triumph that brings satire to paroxysm. Dr. Dragolea introduces a new exam format. It is known that the exam has always been

...the synonym of terror, of the guillotine, even, when the student was driven by fear not only to learn but also to plagiarize, bribe or, horibile dictu, prostitute! ... the exam was a source of corruption and moral decadence, a trauma from which [the student] never recovered ${ }^{86}$.

The traditional exam is replaced by an academic lottery where there are no grades below $7^{87}$. In a dream-like ceremony, the aristocratic ascent of Dragolea is publicly recognized and he is proclaimed Fifi Dracula I, the constitutional voivode of Transylvania and the random king of Romania and Bessarabia (former Republic of Moldova). The academic plot is abandoned in favour of a happy-end seemingly derived from the scripts of Hollywood movies. Muşina's irony descends from academic Olympian heights to everyday politics and societal conventions.

Codrin Liviu Cuţitaru's academic novel, Scriptor sau Cartea transformărilor admirabile [The Scriptor or the Book of Admirable Transformations], grafts

\footnotetext{
${ }^{84}$ Mioritza is a famous Romanian ballad.

${ }^{85}$ Ibidem, pp. 277-278: "Mathew, Mathew, biet englez, biet scoţian zgârcit rătăcit în amurgul vieţii pe plaiuri mioritice, nebănuite plăceri te aşteaptă, dar şi cheltuieli nesăbuite şi suferinţe de neînchipuit! Jennifer e un foc ce pârjoleşte totul în jur, o panteră din selva oscura a Estului plin de mistere [...] Mathew, Mathew, biet englez, biet scoţian zgârcit, luat de valul feromonilor lui Jennifer, amare zile te aşteaptă, mulţi bani vei cheltui şi multe lacrimi vei vărsa! [...] Dar cine şi cum să-1 sfătuiască, cine să1 înveţe ce să facă, din moment ce el era cel trimis de Consiliul Britanic să ne arate nouă, românaşilor de la marginea Europei, ce şi cum să gândim şi să facem, să ne civilizeze?”.

${ }^{86}$ Ibidem, p. 368: “....sinonim cu teroarea, cu ghilotina chiar, în care studentul era împins de frică nu doar să învețe, ci şi să copieze, să dea ciubuce sau, horibile dictu, să se prostitueze! ... examenul era o sursă a corupţiei şi decăderii morale, o trauma din care [studentul] nu-şi mai revenea toată viaţa".

${ }^{87}$ The equivalent of B- in the American system.
} 
metafictional techniques on a campus plot. The novel focuses on several university professors: Boris Mercuti, Victor Olescu, or Petronel Normanu, each one with his own academic destiny and story. Cuţitaru also uses satire and humour but without Muşina's delight in the body and matter. Cuţitaru is much more conceptual. The university is a bureaucratic monster ${ }^{88}$ and the university board is a legislative academic assembly ${ }^{89}$. The much advertised reform of higher education is regarded with mistrust: "in fact, the reform was the magic formula that created a new typology of academic parasites" $"$.

The academic novelists often have a favourite knack to which they come again and again: for Muşina, it was "semiosis"; for Cuţitaru, it is the oxymoronic "pleasure in pain". University life is garnered with long awaited for "research stages abroad". The communist past hangs over the post-communist academic present. Boris Mercuti had been a sort of "enlightened despot" of the publishing houses and cultural journals from all over the country and his pre-1990 political activity functioned as a kind of sterilizer, or inhibitor. After this experience within the Communist leadership Mercuti did not publish anything else. Cuțitaru also approaches a well-known reality of the Romanian academic system: the existence of the intellectual dynasties. For instance, "Mercuti $\mathrm{Sr}$ was Italian, from an important family of interwar physicians who had immigrated to Romania at the beginning of the century" 91 .

Cultural or literary references to the tragic flaw or to several short stories by Edgar Allan Poe spice the text and most probably make it a reading particularly agreeable to a sophisticated, well-read reader. Mercuti Sr dies not without succeeding in writing to his son about a certain box from his wardrobe. It contains, of course, a manuscript. Cuţitaru uses a new variant of the well-known found manuscript motif in order to give fuel his narrative. Upon his deathbed, Mercuti Sr "created a novel's situation"92.

Cuţitaru's academic novel also deals with gender issues. Firstly, a disparity in female academic promotion is noticed. Liana Olescu is way behind her husband who became the rector ${ }^{93}$ of the university. Domestic duties and raising Bobo, the couple's son, prevent Liana from benefiting from all the post-1990 academic opportunities to the same extent as her husband:

Liana had not accompanied Victor to Baltimore - at the beginning of the 1990s - she stayed home in order to take care of Bobo who was at preschool age. [...] She had never succeeded in travelling too much, maternal duties prevented her from being away longer

\footnotetext{
${ }^{88}$ Codrin Liviu Cuţitaru, Scriptor sau Cartea transformărilor admirabile [The Scriptor or the Book of Admirable Transformations], Iași, Polirom, 2017, p. 19: "monstru birocratic".

${ }^{89}$ Ibidem, p. 9: "legiuitori academici".

90 Ibidem, p. 19: "reforma reprezenta de fapt formula magică pentru crearea unei noi tipologii de paraziţi academici".

91 Ibidem, p. 36: "Mercuti-senior era italian, provenind dintr-o importantă familie de medici interbelici, emigrată pe la începutul secolului în România".

${ }^{92}$ Ibidem, p. 51: "[a] creat o situaţie de roman".

${ }^{93}$ In the American system, the president of the university.
} 
than a week (i.e. the ordinary duration of international conferences, the only academic events Liana took the luxury of participating in $)^{94}$.

On the other hand, the delicate problem of sex relations between the male professor and female students is regarded with an indulgence that hides the narrator's comfortable feeling that patriarchy - thank God! - triumphs everywhere and its end is not to be foreseen in the near future: "The unprincipled master-disciple relation? It continues to be a commonplace of the world educational system! As long as it relies on reciprocal consent, it is not worth mentioning" $"$. Corruption, lack of principles, sexual dillydallyings, dalliances of various intensities, are the very bricks of the university fictionalized in this novel:

The rector gave a cold shoulder to the two guests: the man and the woman from his native village. Screamings, again, pleadings, again, intercessions, again, for various "hard working" scoundrels. For sure, they had brought the head secretary a hen so that she facilitates their hearing and probably schedule them before others (doomed to wait in his antechamber for hours on end!). Before them he had just got rid of another "intercession" a graceful dame from the City Council (he couldn't remember her name any more). That female unscrupulously used her charms in order to obtain favours everywhere ${ }^{96}$.

Cuțitaru's academic novel is built on several narrative levels. Inserted narratives such as the narrative from Titus Mercuti's hidden manuscript entitled Confusio - meet and offer multiple perspectives on academic life and literary research. Confesio deals with the relationship between fiction and reality. The power of fiction lies in its capacity to re-invent life, lives. An article published by Petronel Normanu in a students' journal makes several academics tremble. The darkest secrets of their lives seem to have been discovered by the daring student who framed them in metaphorical and metonymical ways that seem to be crystal clear to the culprits. The succession of narrations passes from critical realism (particularly adequate for the academic plot) to a quasi science fiction story (Victor Olescu survives a terrible disease but he takes the form of an enormous eye), and to confessions and ratiocinations about solitude. The five texts authored, in turn, by Titus Mercuti (Confusio), Boris Mercuti (Vigilia), Victor Olescu (Confusio), Petronel Normanu (Conversio), and Cristofor Pigulea (Substitutio), could be compared with the elements of a hand fan. They are separate but also linked by the

94 Ibidem, p. 54: "Liana nu-1 însoţise pe Victor la Baltimore - la începutul anilor '90 - rămânând acasă pentru a avea grijă de preşcolarul Bobo. [...] Nu reuşise nici să călătorească prea mult, datoriile materne împiedicând-o să lipsească din oraş o perioadă mai lungă de o săptămână (adică atât cât durează, în general congresele internationale, singurele manifestări ştiinţifice la care Liana îşi permisese luxul să meargă)".

${ }^{95}$ Ibidem, p. 64: "Relaţia neprincipială maestru-discipol(ă)? Rămâne o banalitate a sistemului educational mondial! Atât timp cât ea se bazează pe consimţământul reciproc, nici nu merită consemnată".

${ }^{96}$ Ibidem, p. 109: "Rectorul îi trată rece pe cei doi, bărbatul şi femeia din satul natal. Iarăşi vaiete, iarăşi rugăminţi, iarăşi intervenții pentru diferite pramatii 'studioase'. Îi aduseseră, fără îndoială, o găină secretareişefe, ca să le faciliteze audienţa şi probabil să-i mai bage şi peste rândul altora (condamnaţi astfel să aştepte în anticameră ore în şir!). Abia scăpase, înaintea lor, de o altă 'pilă' - madama graţioasă de la Sfatul Popular (nu-şi mai amintea cum o chema). Individa îşi folosea nurii fără scrupule pentru a obţine diverse favoruri pretutindeni. 
Scriptor, a generic name for the writing man. The suicide of Stelu Zaucă, former editorin-chief of a literary journal, metaphorically represents the impending end of a culture, the Gutenberg culture.

Codrin Liviu Cuţitaru offers the reader an academic novel where satire, realism, and fantasy combine in a very successful way. The novelist is also an eminent literary scholar and while writing he cannot help looking at his own writing as in a mirror. But this self-reflected scholarship is not pedantic or tiring. Humour and a drop of good quality self-irony make this novel a successful contribution to the Romanian history of the academic novels. If we follow Petér Szekély's classification of metafiction ${ }^{97}$, Cuţitaru uses, in his metafictional academic novel, authorial surrogacy. The author remains outside fiction, the narrator and the author do not coincide, but the author does play with various narrators who offer diverse perspectives and rely on several discourses. With Codrin Liviu Cuţitaru, the academic novel is implanted into a narration about the writer's condition and about the future of our contemporary writerly culture already under a very vigorous attack of the digital.

In conclusion, we can say that the three instances of the Romanian academic novel submitted to our perusal show us a multitude of forms that certainly indicates vitality. There are some lines of continuity, such as the discussion of the forms and strategies of academic power, the formation and the consolidation academic networks, the university gatekeepers' personal and the academic lives. Reality and/ or the need to be as truthful as possible made several contemporary academic novelists tackle dishonesty and plagiarism more vigorously. Sexual appetite, academic romance are also dealt with more insistence. The university mentor is more often than not a heterosexual male or a spinster full of spite. On the other hand, a knowledgeable reader, can easily notice that the Romanian academic novel still has to deal with the presence of sexual or ethnic minorities in the Romanian higher education. For the moment, such stories do not seem to exist or matter, which amounts to the same. The Romanian academic novelist is also much more comfortable with the heterosexual difference and this is all.

\section{BIBLIOGRAPHY}

DCRR - Dicţionarul cronologic al romanului românesc de la origini până la [The Chronological Dictionary of the Romanian Novel from Its Origins to 1989], București, Editura Academiei Române, 2004.

97 See Petér Szekély, The Academic Novel in the Age of Postmodernity: The Anglo-American Metafictional Academic Novel. Unpublished Ph.D. thesis defended at ELTE in Budapest, Hungary, in 2009, http://doktori.btk.elte.hu/lit/szekelypeter/thesis.pdf. Accessed December 20, 2020. There are three techniques in metafiction: the prefatory technique of intrusion, the occasional authorial infiltration, and the authorial surrogacy where the author remains completely outside fiction. 
ANTÉNE, Petr, Campus Novel Variations: A Comparative Study of an Anglo-American Genre, Olomouc, Palacky University Olomouc, 2015.

BEVAN, David, University Fiction, Amsterdam, Rodopi, 1993.

BOSCO, Mark, RAE CONNOR, Kimberley, Academic Novels as Satire: Critical Studies as an Emerging Genre, Lewiston, Edwin Mellen Press, 2007.

BOTTUM, Joseph, "The End of the Academic Novel", Washington Examiner, 9 August 1997, https://www.washingtonexaminer.com/weekly-standard/the-end-of-the-academic-novel. Accessed December 20, 2020.

BROWN, Stephanie, "J. Saunders Redding and the African American Campus Novel", in The Postwar African American Novel: Protest and Discontent, 1945-1950, Jackson, University Press of Mississippi, 2011, pp. 132-160.

BURGESS, Taylor, "A Genre in Discord: The Ubiquity of the Campus Novel”, Wide Angle. A Journal of Literature and Film, 3, 2013, 1, pp. 59-64.

CARTER, Ian, Ancient Cultures of Conceit. British University Fiction in the Post War Years. London, Routledge, 1990.

CUȚITARU, Codrin Liviu, Scriptor sau Cartea transformărilor admirabile [The Scriptor or the Book of Admirable Transformations], Iași, Polirom, 2017.

DALTON-BROWN, Sally, "Is There Life Outside of (the Genre of) the Campus Novel? The Academic Struggles to Find a Place in Today's World", The Journal of Popular Culture, 41, 2008, 4, pp. 591-600.

EVE, Martin Paul, Literature against Criticism: University English and Contemporary Fiction in Conflict, Cambridge, Open Book Publisher, 2016.

FINDEISEN, Christopher, "Injuries of Class: Mass Education and the American Campus Novel", PMLA, 130, 2015, 2, pp. 284-298.

FISCHER, Mike, "Adventures in Academia", Milwaukee Journal Sentinel, 2010, https://archive.jsonline.com/entertainment/arts/101658423.html/. Accessed December 20, 2020.

GUIRAO, Marta, David Lodge's Campus Novels in Spanish Translation: A Comparative Study of Genre and Intertextuality. Unpublished Ph.D. thesis defended at the University of London, 2002, https://discovery.ucl.ac.uk/id/eprint/1382487/. Accessed December 20, 2020.

HAGUE, Angela, "Picaresque Structure and the Angry Young Novel", Twentieth Century Literature, 32, 1968, 2, pp. 209-220.

HAYWOOD, Eliza, The Adventures of Miss Betsy Thoughtless, in Project Gutenberg, 2014, https://www.gutenberg.org/files/46346/46346-h/46346-h.htm. Accessed December 20, 2020.

KAVADLO, Jesse, "Blue Angels Meet Dying Animals: Textual and Sexual Subversion in the Clinton-Era Academic Novel", The Journal of the Midwest Modern Language Association, 37, 2004, 2, pp. 11-25.

KENNY, John, "Lampooning Academia in the Campus Novel", The Irish Times, 15 April 2006, https://www.irishtimes.com/news/lampooning-academia-in-the-campus-novel-1.1038980. Accessed December 20, 2021.

KRAMER, John E, The American College Novel. An Annotated Bibliography, Lanham, Scarecrow Press, 2003.

LEUSCHNER, Eric, "Body Damage: Dis-figuring the Academic in Academic Fiction", The Review of Education, Pedagogy, and Cultural Studies, 28, 2006, 3-4, pp. 339-354.

LODGE, David. "Nabokov and the Campus Novel", 24, Cycnos, 2008, 1, http://revel.unice.fr/cycnos/index.html?id=1081. Accessed December 20, 2020.

LYONS, John O., The College Novel in America. Preface by Harry T. Moore, Chicago, Southern Illinois University Press, 1962.

MERRITT, Moseley (ed.), The Academic Novel: New and Classic Essays, Chester, Chester Academic Press, 2007.

MUŞINA, Alexandru, Nepotul lui Dracula [Dracula's Descendant], Braşov, Aula, 2012.

NASTASĂ, Lucian, "Suveranii" universităţilor româneşti. Mecanisme de selecţie şi promovare a elitei intelectuale [The "Sovereigns" of Romanian Universities. Intellectual Elites' Mechanisms of Selection and Promotion], Cluj-Napoca, Limes, 2007. 
NASTASĂ, Lucian, Intimitatea amfiteatrelor. Ipostaze din viaţa universitarilor "literari" (18641948) [The Intimacy of Amphitheatres. Faces in the Privacy of the "Literary" University Professors (1864-1948)], Cluj-Napoca, Limes, 2010.

POGHOSYAN, Syuzanna, "The Characteristic Features of the Academic Fiction Genre." Armenian Folia Anglistika, 8, 2012, 1-2, pp. 138-145.

PORTER, Lavelle, "The Overeducation of the Negro: On Reading Black Academic Fiction", in The Blackademic Life: Academic Fiction, Higher Education, and the Black Intellectual, Evanston, Northwestern University Press, 2020, pp. 15-44.

PRASANTA, Kumar Padhi, "Indian Campus Novels: An Emerging Genre in Literary Writing", Journal of Humanities and Social Science, 22, 2017, 11, pp. 1-8.

PROCTOR, Mortimer Robinson, The English University Novel, Berkeley, University of California Press, 1957.

RADULESCU, Marta, Sînt studentă!. Reportagii fanteziste [I Am a Student! Imaginary Reportages], București, Editura "Adevărul”, 1933.

REYNOLDS, Katherine, SCHWARTZ, Robert, BOWER, Beverly, "Fear and Laughing in Campus Literature: Contemporary Messages from a Comedic Tradition", The Journal of Educational Thought, 34, 2000, 1, pp. 29-41.

ROSSEN, Janice, The University in Modern Fiction. When Power Is Academic, New York, St. Martin's Press, 1993.

SCOTT, Robert F., "It's a Small World, after All: Assessing the Contemporary Campus Novel", The Journal of the Midwest Modern Language Association, 37, 2004, 1, pp. 81-87.

SELEJAN, Corina, “'How to Save Difference': Contemporary Romanian, German, English and American Academic Novels" in Dieter Fuchs and Vojciech Klepuszwski, (eds.), The Campus Novel: Regional or Global?, Leiden, Brill, 2019, pp. 166-179.

SELEJAN, Corina, "The Romanian Academic Novel and Film through the Postcommunism/ Postcolonialism Lens", Polish Journal of English Studies, 2019, 2, pp. 87-102.

SHOWALTER, Elaine, Faculty Towers: The Academic Novel and Its Discontents, Philadelphia, University of Pennsylvania Press, 2005.

SIMION, Eugen (ed.), Dicţionarul general al literaturii române [The General Dictionary of Romanian Literature], P-R, București, Univers Enciclopedic, 2006.

SMOLLETT, Tobias, The Expedition of Humphry Clinker, in Project Gutenberg, 2016, http://www.gutenberg.org/files/2160/2160-h/2160-h.htm. Accessed December 20, 2020.

SZEKÉLY, Petér, The Academic Novel in the Age of Postmodernity: The Anglo-American Metafictional Academic Novel. Unpublished Ph.D. thesis defended at ELTE in Budapest, Hungary, 2009, http://doktori.btk.elte.hu/lit/szekelypeter/thesis.pdf. Accessed December 20, 2020.

WEISS, Rudolph, "From German to Austrian Academic Fiction: Regionalism Exponentiated", in Dieter Fuchs and Wojciech Klepuszewski (eds.), The Campus Novel: Regional or Global?, Leiden, Brill, 2019, pp. 93-108.

WILLIAMS, Jeffrey J., "The Rise of the Academic Novel”, American Literary History, 24, 2012, 3, pp. 561-589.

WOMACK, Kenneth, Postwar Academic Fiction. Satire, Ethics, Community, London, Palgrave Macmillan, 2002.

ZACIU, Mircea, PAPAHAGI, Marian, SASU, Aurel, Dicţionarul scriitorilor români [The Dictionary of Romanian Writers], R-Z, București, Albatros, 2002.

\section{THREE INSTANCES OF THE ROMANIAN ACADEMIC NOVEL}

(Abstract)

This article starts from a general characterization of the international campus/academic novel and the exploration of its appearance and evolution. Against this frame, the author makes an inventory of the 
Romanian novels belonging to this genre and analyses three samples from various historical periods: Marta Rădulescu's 1933 novel entitled Sint studentă! [I Am a Student!]; Alexandru Muşina's 2012 novel entitled Nepotul lui Dracula [Dracula's Descendant]; and Codrin Liviu Cuţitaru's 2017 novel Scriptor sau Cartea transformărilor admirabile [The Scriptor or the Book of Admirable Transformations]. Continuities and discontinuities point to the vitality of this literary form in Romanian literature, especially after 1990.

Keywords: novel, campus, genre theory, Romanian literature after 2000, university.

\section{TREI IPOSTAZE ALE ROMANULUI UNIVERSITAR ROMÂNESC (Rezumat)}

Articolul porneşte de la o caracterizare generală a romanului universitar şi de la cercetarea apariţiei şi evoluţiei sale. Pe acest fundal, autoarea face un inventar al romanelor aparţinând acestui gen în literatura română şi analizează trei romane din perioade istorice diferite: romanul din 1933 al Martei Rădulescu intitulat Sînt studentă!; romanul din 2012 al lui Alexandru Muşina, intitulat Nepotul lui Dracula, şi romanul Scriptor sau Cartea transformărilor admirabile, publicat de Codrin Liviu Cuţitaru în 2017. Continuităţile şi discontinuităţile dovedesc vitalitatea acestui gen în literatura română, cu precădere după 1990.

Cuvinte-cheie: roman, campus, teoria genului, literatura română după 2000, universitate. 